\title{
Preliminary Evaluation of New Quinoa Genotypes under Sandy Soil Conditions in Egypt
}

\author{
Amr S. Shams \\ Crop Intensification Research Department (CIRD), Field Crops Research Institute (FCRI), Agricultural Research Center (ARC), \\ Giza, Egypt \\ Email: Dr_AmrShams@yahoo.com
}

How to cite this paper: Shams, A.S. (2018) Preliminary Evaluation of New Quinoa Genotypes under Sandy Soil Conditions in Egypt. Agricultural Sciences, 9, 1444-1456. https://doi.org/10.4236/as.2018.911100

Received: October 12, 2018

Accepted: November 19, 2018

Published: November 23, 2018

Copyright $\odot 2018$ by author and Scientific Research Publishing Inc. This work is licensed under the Creative Commons Attribution International License (CC BY 4.0).

http://creativecommons.org/licenses/by/4.0/

\begin{abstract}
Field trial was carried out at Ismailia Research Station, Ismailia Governorate, Egypt to evaluate some quinoa genotypes under arid environment of sandy soil for identifying its agronomic potentiality, chemical composition and economic opportunity. Nine quinoa genotypes including six Peruvian varieties (Amarilla Marangani, Amarilla Sacaca, Blanca de Junin, Kancolla, Salcedo INIA and Rosada de Huancayo) and three new accessions (QS14, QS16 and QS17-2) were compared in randomized complete block design with three replications. The results revealed that quinoa proved success in sandy soil with suitable grain yield under Egyptian conditions. QS17-2 accession stays only from 115 to 120 days in the field according to environmental factors and treated as short duration accession, while growth duration of the four varieties; Blanca de Junin, Kancolla, Salcedo INIA and Rosada de Huancayo, as well as, accessions of QS14 and QS16 were moderate. Amarilla Marangani and Amarilla Sacaca varieties had the longest duration genotypes. Amarilla Sacaca and Amarilla Marangani varieties, as well as, QS17-2 accession gave the highest grain yield compared with the other genotypes. The highest protein content in quinoa grains was $13.60 \%$, which recorded from QS17-2 accession, while the lowest value (10.75\%) was recorded by Blanca de Junin variety. Moreover, Salcedo INIA variety had the lowest saponins content in quinoa grains $(0.07 \%)$ while QS16 accession recorded the highest content $(0.22 \%)$. The economic evaluation gave a clear indicator of the lower farm prices of quinoa grains in Egypt (US\$ 1000/ton), which gives a comparative advantage to Egypt in the MENA region for quinoa exportation.
\end{abstract}

\section{Keywords}

Quinoa Genotypes, Grain Yield, Protein, Saponins, Economic Evaluation 


\section{Introduction}

Always, population growth requires an increase in the use of available environmental resources around the world. It is considerable pressure on available environmental resources especially water that is one of the major factors in arid and semiarid regions [1]. So, it is important to address our efforts to this fundamental issue by increasing food supply to face the highest population growth rates without any increase in the used water duty especially in the developing countries. According to FAO [2], there were around 799 million undernourished people in the developing countries. Recently, quinoa (Chenopodium quinoa Willd.) crop has attracted attention of the Food and Agriculture Organization of the United Nations (FAO) to fight hunger in the $21^{\text {st }}$ century because of its high nutritional value and extreme resistance to adverse environmental conditions.

From several decades, quinoa is a valuable source of protein in some parts of South America; it was cultivated and used by the Inca (ruling class) people since 5000 B.C. It is consumed in wide variety of forms i.e., grains, flakes, pasta, bread, biscuits, beverages, meals etc. Bolivia in South America is the biggest producer of quinoa with 46 percent of world production followed by Peru with 42 percent and United States of America with 6.3 percent. Quinoa is cultivated in the world with an area of 126 thousand ha with a production of 103 thousand ton [3]. Thus, it is likely to be exploited further in both developing and industrialised countries.

So, NASA [4] selected this crop as ideal candidate crop for the Controlled Ecological Life Support System (CELSS). Quinoa can be used to produce gluten-free cereal-based products, and can thus be eaten by people who have celiac disease, as well as, by those who are allergic to wheat because of the absence of gluten proteins [5]. Quinoa have high protein values and essential amino acids including (lysine), fats, flavonoids, vitamins and minerals and as a gluten-free product [6]. Due to the high nutritional value of quinoa, it has been considered an exceptional crop with the potential of contributing to food security worldwide because of its genetic diversity and its great adaptability to stressful environments [7].

Although several cultivars of quinoa contain saponins act as antinutrients, frequently associated with lipids [8], some saponins can form insoluble complexes with minerals, such as zinc and iron, which make the minerals unavailable for absorption in the gut [9]. It is known that saponins in quinoa are basically glycosidic triterpenoids with glucose constitution about $80 \%$ of the weight [10] and concentrated in seed hull [11].

Therefore, several countries in all over the world started in the last years to promote researches for the development of quinoa cultivation; especially the genetic variability of quinoa is huge, with cultivars of quinoa being adapted to growth from sea level to an altitude of over 4000 meters and from cold, highland climates to subtropical conditions. This make it possible to select, adapt, and breed cultivars for a wide range of environmental conditions such as arid or 
humid areas, cold or hot environments, acidic or alkaline soils [12]. Consequently, FAO declared that year 2013 was the international year of quinoa [13]; where this foundation contributed positively to food and nutritional security not only in Egypt but also in Algeria, Iraq, Iran, Lebanon, Mauritania, Sudan and Yemen by supporting of inclusion a new promising quinoa varieties, technology transfer and training program through QUINOA PROJECT-TCP/RAB/3403 "Technical assistance for the introduction of quinoa and appropriation/institutionalization of its production". However, the improvement of quinoa seed quality is challenging and key for food security and has been almost exclusively focused on generating hybrid varieties with lower saponin contents [14].

Accordingly, breeding programs in quinoa should be mainly focused on the generation of better environmentally adapted plants with higher protein and lower saponin contents to develop high-yielding varieties. Evaluation of new introduced accessions, varieties and new accessions resulted from natural crosses among various genotypes is an important target to release new varieties for Egyptian farmers. Hence, growing quinoa can save hard currency by replenishing part of food gap since the crop succeeded to grow economically in new reclaimed sandy soils of Egyptian deserts [15] [16]. Therefore, the objective of this investigation was to evaluate some quinoa genotypes under arid environment of sandy soil for identifying its agronomic potentiality, chemical composition and economic opportunity.

\section{Materials and Methods}

Field trial was carried out at Ismailia Agricultural Research Station, Ismailia Governorate (Lat. $30^{\circ} 35^{\prime} 30^{\prime \prime} \mathrm{N}$, Long. $32^{\circ} 14^{\prime} 50^{\prime \prime} \mathrm{E}, 10 \mathrm{~m}$ above the sea level), Egypt during 2014/2015 and 2015/2016 winter seasons to evaluate some quinoa genotypes under arid environment of sandy soil for identifying its agronomic potentiality, chemical composition and economic opportunity. Nine quinoa genotypes including six Peruvian varieties (Amarilla Marangani, Amarilla Sacaca, Blanca de Junin, Kancolla, Salcedo INIA and Rosada de Huancayo) and three new accessions (QS14, QS16 and QS17-2) were compared in randomized complete block design with three replications. Table 1 shows origin and grain color of the nine quinoa genotypes used in the trial.

Table 1. Origin and grain color of the nine quinoa genotypes.

\begin{tabular}{|c|c|c|c|c|c|}
\hline Varieties & Origin & $\begin{array}{l}\text { Grain } \\
\text { color }\end{array}$ & $\begin{array}{c}\text { Accessions } \\
\text { under development }\end{array}$ & Origin & $\begin{array}{l}\text { Grain } \\
\text { color }\end{array}$ \\
\hline $\begin{array}{c}\text { Amarilla Marangani } \\
\text { Amarilla Sacaca }\end{array}$ & $\begin{array}{l}\text { Peru } \\
\text { Peru }\end{array}$ & $\begin{array}{l}\text { Orange } \\
\text { Yellow }\end{array}$ & $\begin{array}{l}\text { QS14 (selected from } \\
\text { crosses with Blanca) }\end{array}$ & Denmark & Cream \\
\hline $\begin{array}{l}\text { Blanca de Junin } \\
\text { Kancolla }\end{array}$ & $\begin{array}{l}\text { Peru } \\
\text { Peru }\end{array}$ & $\begin{array}{l}\text { Cream } \\
\text { Cream }\end{array}$ & $\begin{array}{l}\text { QS16 (selected from } \\
\text { crosses with Rosada) }\end{array}$ & Denmark & Cream \\
\hline $\begin{array}{c}\text { Salcedo INIA } \\
\text { Rosada de Huancayo }\end{array}$ & $\begin{array}{l}\text { Peru } \\
\text { Peru }\end{array}$ & $\begin{array}{l}\text { Cream } \\
\text { Cream }\end{array}$ & $\begin{array}{l}\text { QS17-2 (selected from crosses } \\
\text { with ancient Pasankalla) }\end{array}$ & Peru & Red \\
\hline
\end{tabular}


The area of each plot was $10.8 \mathrm{~m}^{2}, 2.4 \mathrm{~m}$ in width (4 lines $60 \mathrm{~cm}$ apart) and 4.5 $\mathrm{m}$ in length (one plant per hill distanced at $15 \mathrm{~cm}$ between hills). Quinoa was drilled in lines on $2^{\text {nd }}$ of December 2014 and on $28^{\text {th }}$ of November 2015. Plots were kept free of weeds through hoeing four times. Maize was the preceding summer crop in both seasons. Sprinkler irrigation was the irrigation system. The field was finely prepared and calcium super phosphate $\left(15.5 \% \mathrm{P}_{2} \mathrm{O}_{5}\right)$ was applied during soil preparation at the rate of $476 \mathrm{Kg}$ per ha. Ammonium nitrate (33.5\%) was applied at the rate of $214.2 \mathrm{Kg} \mathrm{N} / \mathrm{ha}$ in five split equal doses, the first after two weeks from planting date and the other doses every two weeks. Table 2 shows Meteorological information data of Ismailia governorate (October-May) in the two growing seasons.

Mechanical and chemical analyses of the soil $(0-30 \mathrm{~cm})$ were done by Water, Soil and Environment Research Institute, ARC (Table 3) according to Jackson [17] and Chapman and Pratt [18]. The experimental soil had 12.65 percent clay, 2.40 percent silt and 84.95 percent sand, and loamy sand texture.

Table 2. Meteorological information data of Ismailia governorate (October-May) in 2014/2015 and 2015/2016 growing seasons.

\begin{tabular}{|c|c|c|c|c|c|c|c|c|}
\hline \multirow{3}{*}{ Months } & \multicolumn{4}{|c|}{$2014 / 2015$} & \multicolumn{4}{|c|}{$2015 / 2016$} \\
\hline & \multicolumn{2}{|c|}{$\begin{array}{c}\text { Temperature } \\
\left({ }^{\circ} \mathrm{C}\right)\end{array}$} & \multirow{2}{*}{$\begin{array}{l}\text { Relative } \\
\text { humidity } \\
\text { (\%) }\end{array}$} & \multirow{2}{*}{$\begin{array}{c}\text { Rain } \\
(\mathrm{mm} / \mathrm{day})\end{array}$} & \multicolumn{2}{|c|}{$\begin{array}{c}\text { Temperature } \\
\left({ }^{\circ} \mathrm{C}\right)\end{array}$} & \multirow{2}{*}{$\begin{array}{c}\text { Relative } \\
\text { humidity } \\
(\%)\end{array}$} & \multirow{2}{*}{$\begin{array}{c}\text { Rain } \\
(\mathrm{mm} / \text { day) }\end{array}$} \\
\hline & $\operatorname{Max}$ & Min & & & $\operatorname{Max}$ & Min & & \\
\hline October & 30.57 & 17.94 & 61.92 & 0.99 & 31.04 & 19.62 & 58.03 & 0.30 \\
\hline November & 25.71 & 14.21 & 58.13 & 1.17 & 25.44 & 14.69 & 63.63 & 0.44 \\
\hline December & 17.88 & 7.61 & 68.70 & 0.52 & 19.78 & 9.67 & 65.32 & 0.25 \\
\hline January & 18.40 & 7.40 & 54.68 & 0.65 & 17.67 & 6.77 & 63.74 & 0.43 \\
\hline February & 19.89 & 7.96 & 50.92 & 0.28 & 23.54 & 9.43 & 53.02 & 0.08 \\
\hline March & 25.08 & 11.16 & 50.81 & 0.13 & 25.02 & 11.19 & 48.28 & 0.09 \\
\hline April & 27.40 & 11.57 & 45.77 & 0.53 & 32.32 & 15.19 & 37.71 & 0.11 \\
\hline May & 32.90 & 16.82 & 40.75 & 0.03 & 33.26 & 17.26 & 38.48 & 0.00 \\
\hline
\end{tabular}

NASA website.

Table 3. Chemical analysis of the experimental soil before growing quinoa genotypes.

\begin{tabular}{ccc}
\hline \multirow{2}{*}{ Chemical analysis } & \multicolumn{2}{c}{ Growing season } \\
\cline { 2 - 3 } $\mathrm{pH}$ & 2014 & 2015 \\
$\mathrm{~N}(\mathrm{ppm})$ & 7.75 & 7.89 \\
$\mathrm{P}(\mathrm{ppm})$ & 19.10 & 19.25 \\
$\mathrm{~K}(\mathrm{ppm})$ & 2.55 & 2.72 \\
Organic matter & 39.07 & 39.28 \\
\hline
\end{tabular}




\section{The studied traits}

\section{Growth duration}

Growth duration was recorded by estimating number of days from sowing to maturity.

\section{Grain yield and its attributes}

The following traits were measured on ten guarded plants from each plot at harvest; plant height $(\mathrm{cm})$, number of branches per plant, 1000-grain weight and grain yield per plant. Grain yield per ha (ton) was recorded on the basis of plot area by harvesting all plants of each plot and converted to yield per ha.

\section{Chemical analysis}

Grain samples from each replicate of best grain yield treatment were taken in the two growing seasons after harvesting and mixed together, left for air drying to $15 \%$ moisture content then sent to laboratory for preliminarily chemical analysis. Grain protein and saponins contents were analyzed by the Regional Center for Food \& Feed, A.R.C., Giza, Egypt according to A.O.A.C. [19].

\section{Economic evaluation}

Production costs and total income in this study were calculated based on averages of collected data from four locations of Ismailia, Sharkia, Behira and Fayoum governorates to standardized the net return for newquinoa farmers compared with wheat in 2015/2016 season [20].

\section{Statistical analysis:}

Data were analyzed using ANOVA in Randomized Complete Block Design with three replications. MSTAT-C [21] was used for statistical computations.

\section{Results and Discussion}

\section{1) Growth duration}

As a result of different agro-ecological extremes (soils, rainfall, temperatures, and altitude) within the areas of origin, quinoa shows a broad genetic diversity and can be divided into five ecotypes highly adapted to specific environments, being tolerant against various abiotic stress factors (frost, drought, and salinity) [22]. Results in Figure 1 show that the QS17-2 accession stays only from 115 to 120 days in the field and treated as short duration accession, while, varieties of Blanca de Junin, Salcedo INIA and Rosada de Huancayo, as well as, accessions of QS14 and QS16 were moderate in their growth duration (140 days in the first season and 134 days in the second one).

Moreover, varieties of Amarilla Marangani, Amarilla Sacaca recorded up to 160 days in the first season and 157 days in the second one which treated as long duration genotypes. It seems that Egyptian climatic and edaphic factors (Table 2 and Table 3) had a major role in growth duration of the studied quinoa genotypes that is a predominantly self-pollinating species indicating considerable variation exists among the genotypes for many of the desired characters. It seems that temperature, relative humidity and rain played a major role in maturity stage of quinoa where the tested quinoa genotypes reached maturity stage 


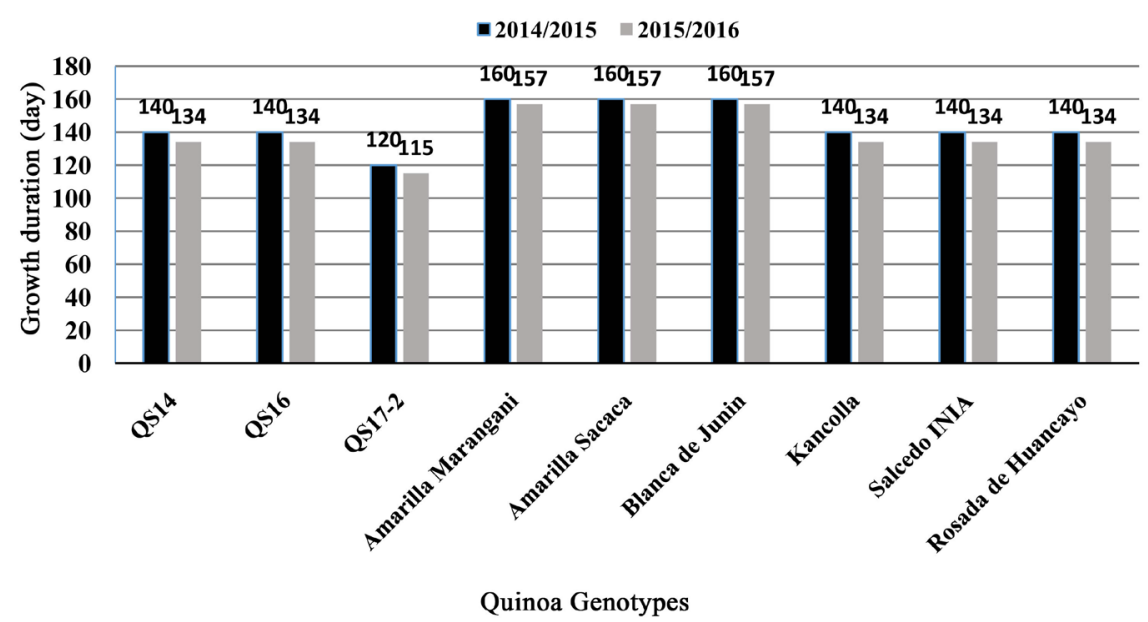

Figure 1. Growth duration of the tested quinoa genotypes in both seasons.

earlier in the second season than the first one. Certainly, the sensitivity against photoperiod is the most important factor in creating new varieties adapted to higher latitudes [23].

\section{2) Grain yield and its attributes}

Results in Table 4 reveal that Amarilla Sacaca variety and QS16 accession were the tallest in the first and second seasons, respectively, whereas Salcedo INIA variety had the shortest ones in the both seasons. These results may be primarily attributed to genetic differences among the genotypes had a major role to interact differently with day length which reflected on their internode elongation under sandy soil conditions. It seems that genetic makeup of quinoa genotypes Amarilla Sacaca and QS16 translated into alteration of plant height growth rate for helping these plants to reach enough light compared with the other genotypes. These results are in the same context with those obtained by Maliroet al. [24] who revealed that Bio-Bio variety grew to a height of $66 \mathrm{~cm}$, followed by Brightest Brilliant Rainbow $(64 \mathrm{~cm})$.

The maximum number of branches per plant was obtained by Amarilla Sacaca variety and QS16 accession in the first and second seasons, respectively, while Kancolla variety had the lowest value of this trait in both seasons. So, it is likely that genetic makeup of quinoa genotypes Amarilla Sacaca and QS16 sustained growth of new branches development during pollination process compared to the other genotypes under sandy soil conditions.

Also, data in Table 4 show that the highest values of 1000-grain weight were recorded by QS17-2 accession, while the lowest values were obtained by Blanca de Junin variety compared with the other genotypes in the both seasons. These results probably due to genetic differences among the studied genotypes differed in assimilates and it's partitioning to the panicle. It seems that QS17-2 accession was more effective in translocating photosynthates from leaves and stalks to the developing panicle compared with the other genotypes under sandy soil conditions. 
Table 4. Grain yield and its attributes of some quinoa genotypes under sandy soil conditions in the two growing seasons.

\begin{tabular}{|c|c|c|c|c|c|}
\hline Genotype & $\begin{array}{l}\text { Plant height } \\
\quad(\mathrm{cm})\end{array}$ & $\begin{array}{c}\text { Number of } \\
\text { branches/plant }\end{array}$ & $\begin{array}{l}\text { 1000-grain } \\
\text { weight }(\mathrm{g})\end{array}$ & $\begin{array}{c}\text { Grain } \\
\text { yield/plant (g) }\end{array}$ & $\begin{array}{c}\text { Grain } \\
\text { yield/ha (ton) }\end{array}$ \\
\hline \multicolumn{6}{|c|}{$2014 / 2015$ season } \\
\hline QS14 & $111_{c}$ & $19_{\mathrm{bc}}$ & $3.0_{\mathrm{e}}$ & $17_{\mathrm{de}}$ & $1.632_{\mathrm{bc}}$ \\
\hline QS16 & $131_{\mathrm{ab}}$ & $22_{\mathrm{ab}}$ & $2.7_{\mathrm{fg}}$ & $18_{\text {cde }}$ & $1.661_{\mathrm{bc}}$ \\
\hline QS17-2 & $97_{d}$ & $16_{\mathrm{cd}}$ & $4.5_{\mathrm{a}}$ & $26_{\mathrm{ab}}$ & $2.100_{\mathrm{ab}}$ \\
\hline Amarilla Marangani & $130_{\mathrm{ab}}$ & $20_{\mathrm{bc}}$ & $3.5_{\mathrm{d}}$ & $26_{\mathrm{ab}}$ & $2.114_{\mathrm{ab}}$ \\
\hline Amarilla Sacaca & $135 \mathrm{a}$ & $25_{\mathrm{a}}$ & $3.7_{\mathrm{c}}$ & $27 \mathrm{a}$ & $2.228_{\mathrm{a}}$ \\
\hline Blanca de Junin & $127_{\mathrm{b}}$ & $19_{b c}$ & $2.5_{\mathrm{g}}$ & $13_{\mathrm{e}}$ & $1.070_{\mathrm{d}}$ \\
\hline Kancolla & $77_{\mathrm{f}}$ & $12_{\mathrm{d}}$ & $4.1_{\mathrm{b}}$ & $23_{\mathrm{abc}}$ & $2.083_{\mathrm{ab}}$ \\
\hline Salcedo INIA & $76_{\mathrm{f}}$ & $14_{\mathrm{d}}$ & $3.9_{\mathrm{bc}}$ & $21_{\text {bcd }}$ & $1.442_{\mathrm{c}}$ \\
\hline Rosada de Huancayo & $90_{\mathrm{e}}$ & $17_{\mathrm{cd}}$ & $2.8_{\mathrm{ef}}$ & $16_{\mathrm{de}}$ & $1.297_{\mathrm{cd}}$ \\
\hline \multicolumn{6}{|c|}{$2015 / 2016$ season } \\
\hline QS14 & $123_{\mathrm{bc}}$ & $21_{\mathrm{ab}}$ & $3.4_{d}$ & $20_{\mathrm{cd}}$ & $1.342_{\mathrm{e}}$ \\
\hline QS16 & $155_{\mathrm{a}}$ & $24_{\mathrm{a}}$ & $2.8_{\mathrm{e}}$ & $24_{b c}$ & $1.926_{\mathrm{cd}}$ \\
\hline QS17-2 & $103_{c}$ & $20_{\mathrm{ab}}$ & $4.7_{\mathrm{a}}$ & $28_{\mathrm{ab}}$ & $2.680_{\mathrm{ab}}$ \\
\hline Amarilla Marangani & $145_{\mathrm{ab}}$ & $20_{\mathrm{ab}}$ & $3.7_{\mathrm{c}}$ & $28_{\mathrm{abc}}$ & $2.404_{\mathrm{ab}}$ \\
\hline Amarilla Sacaca & $146_{\mathrm{ab}}$ & $20_{\mathrm{ab}}$ & $3.8_{\mathrm{c}}$ & $31_{\mathrm{a}}$ & $2.747 \mathrm{a}$ \\
\hline Blanca de Junin & $123_{\mathrm{bc}}$ & $23_{\mathrm{ab}}$ & $2.6_{\mathrm{e}}$ & $17_{\mathrm{d}}$ & $1.163_{\mathrm{e}}$ \\
\hline Kancolla & $118_{\mathrm{bc}}$ & $16_{\mathrm{b}}$ & $4.3_{\mathrm{b}}$ & $26_{\mathrm{abc}}$ & $2.253_{\mathrm{bc}}$ \\
\hline Salcedo INIA & $97_{c}$ & $18_{\mathrm{ab}}$ & $4.1_{\mathrm{b}}$ & $22_{\mathrm{bcd}}$ & $1.638_{\mathrm{de}}$ \\
\hline Rosada de Huancayo & $107_{c}$ & $18_{\mathrm{ab}}$ & $2.9_{\mathrm{e}}$ & $21_{\mathrm{cd}}$ & $1.527_{\mathrm{de}}$ \\
\hline
\end{tabular}

In case of grain yields per plant and per ha, the results indicate clearly that the highest values of these traits were recorded by the quinoa genotypes Amarilla Sacaca, Amarilla Marangani, QS17-2 and Kancolla, while Blanca de Junin variety had the lowest values of these traits in the both seasons. These results may be attributed to yield potential of the studied quinoa genotypes related to the genetic differences that reflected on differ in their competitive abilities for assimilate distribution between organs of quinoa plant. So, it may be possible that genetic potential of the quinoa genotypes Amarilla Sacaca, Amarilla Marangani, QS17-2 and Kancolla translated into suitable canopy architecture that induced a deeper root system and a faster horizontal root development, indicting efficient use of all nutrients by all parts of these genotypes compared to the other genotypes.

Accordingly, these results reveal that quinoa proved success in desert lands with suitable grain yield. Similar results were obtained by Zuniga et al. [25] who evaluated the productivity of Amarilla Sacaca and Amarilla Marangani varieties and they found that the both varieties produced more than 2.3 ton/ha with the 
superiorty to Amarilla Sacaca variety. Also, Huaringa [26] tested ten varieties of quinoa (Blanca de Hualhuas, Rosada de Huancayo, INIA 415-Pasankalla, Kancolla, Illpa - INIA, Blanca de Juli, Salcedo - INIA, INIA 420-NegraCollana, INIA 431 - Altiplano and Amarilla de Marangani). He mentioned that the superiority of Amarilla de Marangani variety over the rest of varieties with yield of 3.5 ton/ha. Moreover, these results are in accordance with those obtained by Shams [27].

\section{3) Chemical composition}

Data in Table 5 reveal that the maximum protein content in quinoa grains were recorded with QS17-2 (13.77\% in the first season and 13.43\% in the second one), QS16 (12.88\% in the first season and $12.76 \%$ in the second one) and Rosada de Huancayo ( $12.38 \%$ in the first season and $12.22 \%$ in the second one), meanwhile the lowest protein contend was recorded by Blanca de Junin variety (10.83\% in the first season and $10.67 \%$ in the second one). These findings are parallel with those obtained by Huaringa [26] who showed that the protein content in Salcedo INIA was higher than those in Kancolla and Amarilla Marangani, respectively. It is known that the nutritional properties, especially the high protein contents or rather the well-balanced composition of proteogenic amino acids, are two of the most promising features of quinoa [28].

Table 5. Protein and saponins in grains of some quinoa genotypes.

\begin{tabular}{|c|c|c|}
\hline Genotype Trait & Protein (\%) & Total Saponins (\%) \\
\hline \multicolumn{3}{|c|}{$2014 / 2015$ season } \\
\hline QS14 & $11.37_{\mathrm{f}}$ & $0.184_{\mathrm{b}}$ \\
\hline QS16 & $12.88_{\mathrm{b}}$ & $0.222_{\mathrm{a}}$ \\
\hline QS17-2 & $13.77_{\mathrm{a}}$ & $0.132_{\mathrm{d}}$ \\
\hline Amarilla Marangani & $10.96_{\mathrm{g}}$ & $0.129_{\mathrm{d}}$ \\
\hline Amarilla Sacaca & $12.02_{\mathrm{de}}$ & $0.164_{c}$ \\
\hline Blanca de Junin & $10.83_{\mathrm{g}}$ & $0.093_{\mathrm{e}}$ \\
\hline Kancolla & $11.86_{\mathrm{e}}$ & $0.130_{\mathrm{d}}$ \\
\hline Salcedo INIA & $12.26_{\mathrm{cd}}$ & $0.076_{\mathrm{f}}$ \\
\hline Rosada de Huancayo & $12.38_{\mathrm{c}}$ & $0.143_{\mathrm{d}}$ \\
\hline \multicolumn{3}{|c|}{$2015 / 2016$ season } \\
\hline QS14 & $11.03_{\mathrm{f}}$ & $0.156_{\mathrm{b}}$ \\
\hline QS16 & $12.76_{\mathrm{b}}$ & $0.214 \mathrm{a}$ \\
\hline QS17-2 & $13.43_{\mathrm{a}}$ & $0.120_{c}$ \\
\hline Amarilla Marangani & $10.82_{\mathrm{fg}}$ & $0.119_{\mathrm{c}}$ \\
\hline Amarilla Sacaca & $11.86_{\mathrm{d}}$ & $0.154_{\mathrm{b}}$ \\
\hline Blanca de Junin & $10.67 \mathrm{~g}$ & $0.085_{\mathrm{d}}$ \\
\hline Kancolla & $11.60_{\mathrm{e}}$ & $0.120_{c}$ \\
\hline Salcedo INIA & $11.96_{\mathrm{d}}$ & $0.064_{\mathrm{e}}$ \\
\hline Rosada de Huancayo & $12.22_{\mathrm{c}}$ & $0.133_{\mathrm{c}}$ \\
\hline
\end{tabular}


On the other hand, the saponins content values in quinoa grains were recorded for Salcedo INIA $(0.076 \%$ in the first season and $0.064 \%$ in the second one), Blanca de Junin $(0.093 \%$ in the first season and $0.085 \%$ in the second one), Amarilla Marangani $(0.129 \%$ in the first season and $0.119 \%$ in the second one), Kancolla $(0.130 \%$ in the first season and $0.120 \%$ in the second one), QS17-2 $(0.132 \%$ in the first season and $0.120 \%$ in the second one), Rosada de Huancayo $(0.143 \%$ in the first season and $0.133 \%$ in the second one), Amarilla Sacaca ( $0.164 \%$ in the first season and $0.154 \%$ in the second one), QS14 $(0.184 \%$ in the first season and $0.156 \%$ in the second one) and QS16 (0.222\% in the first season and $0.214 \%$ in the second one), respectively. These results could be attributed to limited supply of water affected negatively the formation of saponins contained in quinoa seeds during the growth and development stages; and this effect was increased or decreased according to quinoa genotype that grown under sandy soil conditions, therefore deficit irrigation can be used as sustainable practice to reduce saponin levels in quinoa seeds [29]. It seems that quinoa genotypes QS17-2, QS16 and Rosada de Huancayo regulate the production of bioactive compounds more than the rest genotypes, influencing its nutritional and industrial values.

\section{4) Economic evaluation}

Data in Table 6 indicate clearly that production costs for quinoa and wheat did not exceed the one thousand US\$/ha including land rent.

Amarilla Sacaca variety gave the highest net return of US\$ 1509 in local market followed by QS17-2 accession and Amarilla Marangani variety, while wheat gave the lowest total income and net return (Table 7).

Table 6. Average costs of production per hectare for quinoa compared with wheatcrop (US\$ $\left.{ }^{*} / \mathrm{ha}\right)$.

\begin{tabular}{ccc} 
Item with Description & Quinoa & Wheat \\
\hline Land preparation (Plowingtwo times) & 24 & 12 \\
Seeds cost (10 Kg of quinoa and 71 kg of wheat) & 10 & 10 \\
Sowing (6 workers ${ }^{* *}$ for Quinoa and 2 for wheat) & 30 & 135 \\
Fertilizers (30 kg $\mathbf{P}_{2} \mathrm{O}_{5}$ and 100 Kg N for both) & 135 \\
Fertilization and Irrigation (Per season) & 40 & 120 \\
Weeding (Hoeing two times for quinoa) & 120 & 180 \\
Harvesting (19 workers for quinoa and 24 for wheat) & 95 & 536 \\
Sub-total without land rent & 180 & 357 \\
Land rent (Per hectare) & 634 & 357
\end{tabular}

${ }^{\star}$ All costs at the exchange rate of $(1$ US\$ $=20$ EGP $) .{ }^{*}$ Workers wages based on ( 5 US\$ for worker/day). 
Table 7. Economic evaluation of new quinoa genotypes under sandy soil conditions compared with wheat crop.

\begin{tabular}{|c|c|c|c|c|c|}
\hline \multirow{2}{*}{$\begin{array}{c}\text { Trait } \\
\text { Genotype }\end{array}$} & \multirow{2}{*}{$\begin{array}{c}\text { Average } \\
\text { grain yield } \\
\text { (ton/ha) }\end{array}$} & \multicolumn{2}{|c|}{$\begin{array}{l}\text { Evaluation based on } \\
\text { Egyptian prices }\end{array}$} & \multicolumn{2}{|c|}{$\begin{array}{l}\text { Evaluation based on } \\
\text { International prices }\end{array}$} \\
\hline & & $\begin{array}{c}\text { Total income } \\
\text { (US\$/ha) }\end{array}$ & $\begin{array}{c}\text { Net return } \\
(\mathrm{US} \$ / \mathrm{ha})\end{array}$ & $\begin{array}{c}\text { Total income }^{*} \\
\text { (US\$/ha) }\end{array}$ & $\begin{array}{c}\text { Net return } \\
\text { (US\$/ha) }\end{array}$ \\
\hline QS14 & 1.5 & 1500 & 509 & 1751 & 760 \\
\hline QS16 & 1.8 & 1800 & 809 & 2101 & 1110 \\
\hline QS17-2 & 2.4 & 2400 & 1409 & 2801 & 1810 \\
\hline Amarilla Marangani & 2.3 & 2300 & 1309 & 2684 & 1693 \\
\hline Amarilla Sacaca & 2.5 & 2500 & 1509 & 2918 & 1927 \\
\hline Blanca de Junin & 1.2 & 1200 & 209 & 1400 & 409 \\
\hline Kancolla & 2.2 & 2200 & 1209 & 2567 & 1576 \\
\hline Salcedo INIA & 1.5 & 1500 & 509 & 1751 & 760 \\
\hline Rosada de Huancayo & 1.4 & 1400 & 409 & 1634 & 643 \\
\hline Wheat & - & 1174 & 281 & - & - \\
\hline Wheat grains & 7.1 & 994 & - & - & - \\
\hline Wheat straw & 6 & 180 & - & - & - \\
\hline
\end{tabular}

*Price of quinoa grains (US\$ 1167/ton), source FAOSt at data, 2017. ${ }^{*}$ Farm prices in Egypt (quinoa grains $=$ US $\$ 1000 /$ ton) and (wheat grains $=$ US $\$ 140 /$ ton $\&$ wheat straw $=$ US $\$ 30 /$ ton), source (Shams, 2016).

The results also gave a clear indicator of the lower farm prices of quinoa grains in Egypt (1 US\$/Kg) compared to international farm prices (from 1.167 up to $2.773 \mathrm{US} \$ / \mathrm{Kg}$ ) [30], which gives a comparative advantage to Egypt in the MENA region for agricultural investment especially in growing quinoa crop for exportation which increase the net return at least by $28 \%$ with possibility of more increases with adding values of removing saponins, grading, sorting and packaging. These results are in agreement with those recorded by Jacobsen [12] who reported that the economic result for the farmer depends on the yield and the price to be achieved for the crop and add that any improved result will be obtained with either an increased yield or a higher price. Also, Shams [16] found that quinoa can be grown under harsh conditions of sandy soils, arid environment.

\section{Conclusion}

Quinoa crop is recommended to replenish part of cereals gap where it can grow successfully and competitively with high profitability to the small-scale farmers under sandy soil conditions. The nutritional composition of quinoa varied among genotypes due to strong genetic variability in addition to environmental differences; this diversity can be the basis for possible adaptations in the fight against cereal gap. QS17-2 is new red quinoa accession for more selection and development to produce a new competitor colored and short duration quinoa 
variety. The economic evaluation gave a clear indicator of the lower farm prices of quinoa grains in Egypt, which gives a comparative advantage to Egypt in the MENA region for quinoa exportation.

\section{Acknowledgements}

Author would like to express of my gratitude and sincere appreciation to Green Desert Egypt Association (GDEA); FAO "Dr. Dost Muhammad, FAO-RNE; FAO-Egypt; FAO-Peru; FAO-RLC" and INIA-Peru and Dr. Luz Rayda, La Molina Univ., Peru, for supporting with quinoa seeds.

\section{Conflicts of Interest}

The author declares no conflicts of interest regarding the publication of this paper.

\section{References}

[1] Walker, W.R. and Skogerboe, G.V. (1987) Surface Irrigation: Theory and Practice. Prentice-Hall Inc., Englewood Cliffs, xiii, 386 p.

[2] FAO (2003) The State of Food Insecurity in the World. Food and Agriculture Organization of the United Nations, Rome.

[3] FAOSTAT (2013) Quinoa Area and Production in the World. http://www.fao.org

[4] NASA (1993) Quinoa: An Emerging New Crop with Potential for CELSS. NASA Technical Paper 3422.

[5] Chillo, S., Civica, V., Lannetti, M., Suriano, N., Mastromatteo, M. and Del Nobile, M.A. (2009) Properties of Quinoa and Oat Spaghetti Loaded with Carboxymethyl Cellulose Sodium Salt and Pregelatinized Starch as Structuring Agents. Carbohydrate Polymers, 78, 932-937. https://doi.org/10.1016/j.carbpol.2009.07.013

[6] Lutz, M., Martínez, A. and Martínez, E.A. (2013) Daidzein and Genistein Contents in Seeds of Quinoa (Chenopodium quinoa Willd.) from Local Ecotypes Grown in Arid Chile. Industrial Crops and Products, 49, 117-121. https://doi.org/10.1016/j.indcrop.2013.04.023

[7] Bazile, D., Pulvento, C., Verniau, A., Al-Nusairi, M.S., Ba, D., Breidy, J., Hassan, L., Mohammed, M.I., Mambetov, O., Otambekova, M., Sepahvand, N.A., Shams, A.S., Souici, D., Miri, Kh. and Padulosi, S. (2016) Worldwide Evaluations of Quinoa: Preliminary Results from Post International Year of Quinoa FAO Projects in Nine Countries. Frontiers in Plant Science, 7, 850. https://doi.org/10.3389/fpls.2016.00850

[8] Jenkins, D. (1988) Carbohydates (B) Dietary Fiber. In: Shil, M. and Young, V., Eds., Modern Nutrition in Health and Disease, Lea and Febiger, Philadelphia, 52-71.

[9] Valencia-Chamorro, S.A. (2003) Quinoa: Saponins. Encyclopedia of Food Sciences and Nutrition, 2nd Edition.

[10] Bhargava, A., Shukla, S. and Ohri, D. (2006) Chenopodium quinoa-An Indian Perspective. Industrial Crops and Products, 23, 73-87. https://doi.org/10.1016/j.indcrop.2005.04.002

[11] Szakiel, A., Paczkowski, C. and Henry, M. (2011) Influence of Environmental Abiotic Factors on the Content of Saponins in Plants. Phytochemistry Reviews, 10, 471-491. https://doi.org/10.1007/s11101-010-9177-x 
[12] Jacobsen, S.E. (2003) The Worldwide Potential for Quinoa (Chenopodium quinoa Willd.). Food Reviews International, 19, 167-177. https://doi.org/10.1081/FRI-120018883

[13] FAO (2013) The State of Food Insecurity in the World. Food and Agriculture Organization of the United Nations, Rome.

[14] Zurita-Silva, A., Fuentes, F., Zamora, P., Jacobsen, S.E. and Schwember, A.R. (2014) Breeding Quinoa (Chenopodium quinoa Willd.): Potential and Perspectives. Molecular Breeding, 34, 13-30. https://doi.org/10.1007/s11032-014-0023-5

[15] Shams, A.S. (2010) Combat Degradation in Rainfed Areas by Introducing New Drought Tolerant Crops in Egypt. 4th International Conference on Water Resources and Arid Environments, Riyadh, 5-8 December 2010, 575-582.

[16] Shams, A.S. (2012) Response of Quinoa to Nitrogen Fertilizer Rates under Sandy Soil Conditions. 13th International Conference on Agronomy, Benha, 9-10 September 2012.

[17] Jackson, M.L. (1958) Soil Chemical Analysis. Prentice Hall, Englwood Cliffis.

[18] Chapman, H.D. and Pratt, P.E. (1961) Methods of Analysis for Soil, Plant and Water. University of California, Oakland.

[19] A.O.A.C. (2007) Association of Official of Analytical Chemists, Official Methods of Analysis. 18th Edition, Washington DC.

[20] Shams, A.S. (2016) Quinoa Evaluation and Scaling up of Improved Varieties in Egypt. FAO Quinoa Workshop, Beirut, 28 September 2016.

[21] MSTAT-C (1988) A Micro-Computer Program for the Design, Management, and Analysis of Agronomic Research Experiments. Michigan State University, East Lansing.

[22] Fuentes, F.F., Bazile, D., Bhargava, A. and Martínez, E.A. (2012) Implications of Farmers' Seed Exchanges for On-Farm Conservation of Quinoa, as Revealed by Its Genetic Diversity in Chile. The Journal of Agricultural Science, 150, 702-716. https://doi.org/10.1017/S0021859612000056

[23] Bertero, H.D. (2001) Effects of Photoperiod, Temperature and Radiation on the Rate of Leaf Appearance in Quinoa (Chenopodium quinoa Willd.) under Field Conditions. Annals of Botany, 87, 495-502. https://doi.org/10.1006/anbo.2000.1362

[24] Maliro, M.F.A., Guwela, V.F., Nyaika, J. and Murphy, K.M. (2017) Preliminary Studies of the Performance of Quinoa (Chenopodium quinoa Willd.) Genotypes under Irrigated and Rainfed Conditions of Central Malawi. Front Plant Science, 8, 227. https://doi.org/10.3389/fpls.2017.00227

[25] Zuniga, R.E., Cusipuma, V.A.G., Vasquez, H.A. and Quispe, J.A. (2011) Technical File of the New Variety of Quinoa INIA 427 Yellow Sacaca. INIA.

[26] Huaringa, G.F.R. (2015) Agronomic Evaluation of Ten Varieties of Quinoa (Chenopodium quinoa Willd.) under the Systems of Cultivation in the Union-Leticia, Tarma. PhD Thesis, National Agric. Univ. La Molina, Lima.

[27] Shams, A.S. (2015) Potential of Quinoa Crop as an Ally to Nutrition and Food Security in Egypt: An Overview of Field Evaluations, Challenges and Recommendations. Wrap up Workshop of Regional Quinoa Project, Beirut, 27-28 October 2015.

[28] Repo-Carrasco, R., Espinoza, C. and Jacobsen, S.E. (2003) Nutritional Value and Use of the Andean Crops Quinoa (Chenopodium quinoa) and Kañiwa (Chenopodium pallidicaule). Food Reviews International, 19, 179-189.

https://doi.org/10.1081/FRI-120018884 
[29] De Santis, G., Maddaluno, C., D’Ambrosio, T., Rascio, A., Rinaldi, M. and Troisi, J. (2016) Characterisation of Quinoa (Chenopodium quinoa Willd.) Accessions for the Saponin Content in Mediterranean Environment. Italian Journal of Agronomy, 11, 277-281. https://doi.org/10.4081/ija.2016.774

[30] FAO (2017) FAOStat Data. http://faostat.fao.org 